\title{
Green synthesis of silver nanoparticles using Ganoderma neo-japonicum Imazeki: a potential cytotoxic agent against breast cancer cells
}

This article was published in the following Dove Press journal:

International Journal of Nanomedicine

14 November 2013

Number of times this article has been viewed

\author{
Sangiliyandi Gurunathan' \\ Jegadeesh Raman ${ }^{2}$ \\ Sri Nurestri Abd Malek ${ }^{2}$ \\ Priscilla A John ${ }^{2}$ \\ Sabaratnam Vikineswary ${ }^{2}$ \\ 'Department of Animal \\ Biotechnology, Konkuk University, \\ Seoul, South Korea; ${ }^{2}$ Mushroom \\ Research Centre, University of \\ Malaya, Kuala Lumpur, Malaysia
}

Background: Silver nanoparticles (AgNPs) are an important class of nanomaterial for a wide range of industrial and biomedical applications. AgNPs have been used as antimicrobial and disinfectant agents due their detrimental effect on target cells. The aim of our study was to determine the cytotoxic effects of biologically synthesized AgNPs using hot aqueous extracts of the mycelia of Ganoderma neo-japonicum Imazeki on MDA-MB-231 human breast cancer cells. Methods: We developed a green method for the synthesis of water-soluble AgNPs by treating silver ions with hot aqueous extract of the mycelia of $G$. neo-japonicum. The formation of AgNPs was characterized by ultraviolet-visible absorption spectroscopy, X-ray diffraction, dynamic light scattering, and transmission electron microscopy. Furthermore, the toxicity of synthesized AgNPs was evaluated using a series of assays: such as cell viability, lactate dehydrogenase leakage, reactive oxygen species generation, caspase 3, DNA laddering, and terminal deoxynucleotidyl transferase deoxyuridine triphosphate nick-end labeling in human breast cancer cells (MDA-MB-231).

Results: The ultraviolet-visible absorption spectroscopy results showed a strong resonance centered on the surface of AgNPs at $420 \mathrm{~nm}$. The X-ray diffraction analysis confirmed that the synthesized AgNPs were single-crystalline, corresponding with the result of transmission electron microscopy. Treatment of MDA-MB-231 breast cancer cells with various concentrations of AgNPs (1-10 $\mu \mathrm{g} / \mathrm{mL})$ for 24 hours revealed that AgNPs could inhibit cell viability and induce membrane leakage in a dose-dependent manner. Cells exposed to AgNPs showed increased reactive oxygen species and hydroxyl radical production. Furthermore, the apoptotic effects of AgNPs were confirmed by activation of caspase 3 and DNA nuclear fragmentation.

Conclusion: The results indicate that AgNPs possess cytotoxic effects with apoptotic features and suggest that the reactive oxygen species generated by AgNPs have a significant role in apoptosis. The present findings suggest that AgNPs could contribute to the development of a suitable anticancer drug, which may lead to the development of a novel nanomedicine for the treatment of cancers.

Keywords: AgNPs, Ganoderma neo-japonicum, human breast cancer cells, cytotoxicity, caspase-3 activity, DNA fragmentation

\section{Introduction}

Nanotechnology is a most promising arena for generating new applications in biotechnology and nanomedicine. ${ }^{1}$ Silver nanoparticles (AgNPs) have become increasingly popular as an antibiotic agent in textiles and wound dressings, medical devices, and appliances, such as refrigerators and washing machines. ${ }^{2}$ Among several nanoproducts, a most prominent nanoproduct is nanosilver. AgNPs have been used for antimicrobial, antifungal, antioxidant, and anti-inflammatory effects. ${ }^{3}$ Nanobiotechnology is the most 
promising field for generating new kinds of nanomaterials for biomedical applications. ${ }^{4}$ Various natural resources have been used for green synthesis of NPs: plants, plant products, bacteria, fungi, algae, yeast, and viruses. ${ }^{5}$ The most commonly preferred method is using bacteria or fungi due to the fact that they are easy to handle, and genetic manipulation is also possible. ${ }^{6}$ In general, NPs are prepared using conventional means, such as physical and chemical methods. However, physical methods give a low yield, ${ }^{4}$ and chemical methods are toxic to the environment due to usage of toxic chemicalreducing agents, such as citrate, borohydride, or other organic compounds, and also it is difficult to prepare AgNPs with welldefined size, whereas biological methods involve synthesis of AgNPs by means of enzymatic reduction, with better control over the shape and size of the NPs., ${ }^{7,8}$ Since the control of particle shape is a factor for various biomedical applications, the biological system is better able to control particle size and morphology than chemical or physical methods of nanoparticle synthesis. By varying such parameters as microorganism type, growth stage of microbial cells, growth medium, synthesis conditions, $\mathrm{pH}$, substrate concentrations, source compound of target NPs, temperature, reaction time, and the addition of nontarget ions, it might be possible to obtain sufficient control of particle size and monodispersity. ${ }^{9,10}$ Biological methods are also valuable in that the NPs are sometimes coated with a lipid layer that confers physiological solubility and stability, which is critical for biomedical applications and is the bottleneck of other synthetic methods. ${ }^{10}$ Besides these, biological methods have several additional merits, such as low toxicity, cost-effectiveness, biocompatibility, stability, and significant dispersity, and do not flocculate. ${ }^{11}$ Therefore, it is essential to look for alternative sources for synthesis of AgNPs using fungi.

Due to their potential medicinal values, culinary and medicinal mushrooms have attracted intense interest in alternative medicine. Extracts of medicinal mushrooms have long been an important part of traditional Oriental medicine. Ling-Sing Seow et $\mathrm{al}^{12}$ reported that Ganoderma neo-japonicum extract possessed neuritogenic effects. A white-rot basidiomycete, Ganoderma spp. have long been used as a medicinal mushroom in Asia, and it has an array of pharmacological properties, including immunomodulatory activity. Several researchers attempted to use fungi as a platform for synthesis of AgNPs and gold NPs, eg, Verticillium, ${ }^{13}$ Fusarium oxysporum, ${ }^{14}$ Aspergillus fumigatus, ${ }^{15}$ Penicillium fellutanum, ${ }^{16}$ Volvariella volvacea,${ }^{17}$ Pleurotus florida,${ }^{18}$ and Candida ${ }^{19}$ as reducing agents. Further, medicinal mushrooms like G. lucidum have been shown to synthesize NPs using extracellular methods, and the produced AgNPs showed sizes between 10 and $70 \mathrm{~nm}$, with an average size of $45 \mathrm{~nm} .^{20,21} \mathrm{In}$ addition, mushroom-derived AgNPs show strong stability, due to amide linkages and protein capping. ${ }^{20,21}$ The cell-free extract of Penicillium spp. shows sizes between 10 and $100 \mathrm{~nm}$, with an average size of $60 \mathrm{~nm} .{ }^{22}$ Jaidev and Narasimha ${ }^{23}$ reported that $A$. niger assisted extracellular synthesis of AgNPs, showing a size range between 3 and $30 \mathrm{~nm}$. Several studies have been reported that used a biological system for synthesis of AgNPs, including treating $\mathrm{AgNO}_{3}$ solution with the culture supernatant of A. terreus. The synthesized AgNPs using $A$. terreus were polydispersed spherical particles ranging in size from 1 to $20 \mathrm{~nm} .{ }^{24}$ The fungus $A$. flavus accumulated a size of $8 \mathrm{~nm}$ in the cell wall. ${ }^{25}$ AgNPs were synthesized using an aqueous extract of Agaricus bisporus fungi, and synthesis revealed that they were of spherical shape and 8-20 $\mathrm{nm}$ in size, and showed a dose-dependent cytotoxic effect on MCF-7 breast cancer cells, with a median lethal dose of $50 \mu \mathrm{g} / \mathrm{mL} .^{11}$

Cancer is the most important cause of mortality in the world. Breast cancer is the second most common cause of cancer death in women. ${ }^{26,27}$ Many cancers initially respond to chemotherapy, but later develop resistance. ${ }^{28,29}$ Currently available chemopreventives and chemotherapeutic agents cause undesirable side effects; ${ }^{30,31}$ therefore, developing a biocompatible and cost-effective method of treatment for cancer is indispensable. Cytotoxic agents used for its treatment are expensive and known to induce several side effects, such as anemia and most importantly the generation of cellular resistance. For this, it is important to find alternative therapies or drugs to overcome these drawbacks. ${ }^{32}$ Nanotechnology has contributed in several applications, such as therapeutics, ${ }^{33}$ catalysis, ${ }^{34}$ biosensing devices,${ }^{35}$ biomedicine due to its ready manufacturing process, ${ }^{36}$ quality control, and biocompatibility, and indeed its use in wound healing and antibacterial applications are already part of clinical practice. ${ }^{22,37}$ AgNPs have been shown to induce the apoptotic pathway in vitro through free oxygen radical generation, which showed antitumor, antiproliferative, and antiangiogenic effects in vitro. ${ }^{38-43}$

AgNPs are gaining much interest among the emerging nanoproducts in the field of nanomedicine due to their unique properties and obvious therapeutic potential in treating a variety of diseases, including retinal neovascularization. ${ }^{38}$ AshaRani et $\mathrm{al}^{39}$ reported that AgNPs inhibit proliferation of human glioblastoma cells. Franco-Molina et al ${ }^{32}$ evaluated the effects of colloidal silver on MCF-7 human breast cancer cells. Sanpui et $\mathrm{al}^{44}$ demonstrated that AgNPs not only 
disrupted normal cellular function but also affected membrane integrity, inducing various apoptotic signaling genes of mammalian cells, leading to programmed cell death. Hsin et $\mathrm{al}^{45}$ reported that AgNPs induced apoptosis in NIH 3T3 (murine embryonic fibroblasts) cells by heightening reactive oxygen species (ROS) generation and activating the c-Jun N-terminal kinase pathway, leading to mitochondria-dependent apoptosis. Several cytotoxic agents have been used in the treatment of breast cancer, such as doxorubicin, cisplatin, and bleomycin, providing beneficial effects, but the efficacy and demerits are unclear. ${ }^{32}$ Therefore, it is necessary to find novel therapeutic agents against cancer that are biocompatible and cost-effective. In this study, we firstly performed synthesis of AgNPs using G. neo-japonicum extract. Secondly, the cytotoxic effect of biologically synthesized AgNPs was investigated in MDA-MB-231 human breast cancer cells. Thirdly, the probable mechanism of cell death caused by AgNPs was addressed with a series of assays, such as lactate dehydrogenase (LDH) leakage, ROS generation, caspase-3 activity, and DNA fragmentation.

\section{Materials and methods Materials}

Penicillin-streptomycin solution, trypsin-ethylenediaminetetraacetic acid (EDTA) solution, Roswell Park Memorial Institute 1640 medium, Dulbecco's Modified Eagle's Medium (DMEM; F-12), and 1\% antibiotic-antimycotic solution were obtained from Life Technologies (Carlsbad, CA, USA). A fetal bovine serum in vitro toxicology assay kit was purchased from Sigma-Aldrich (St Louis, MO, USA).

\section{Culturing and maintenance of Ganoderma neo-japonicum}

The culture of G. neo-japonicum Imazeki KUM61076 was obtained from the Mushroom Research Centre, University of Malaya. The mycelia were cultured on potato dextrose agar and incubated at $28^{\circ} \mathrm{C} \pm 2{ }^{\circ} \mathrm{C}$ for 7 days. The mycelia were then transferred to glucose yeast malt peptone broth. ${ }^{46}$ The inoculated medium was incubated at $28^{\circ} \mathrm{C} \pm 2{ }^{\circ} \mathrm{C}$ and agitated at $150 \mathrm{rpm}$ for 10 days. After incubation, the mycelia were harvested and washed with distilled water. The mycelia were freeze-dried and stored at $4^{\circ} \mathrm{C}$ in air-tight containers prior to use.

\section{Preparation of mycelia hot aqueous extract}

The preparation of mushroom extract was carried out according to a method described earlier. ${ }^{47}$ In brief, the freeze-dried mycelia were soaked in distilled water at a ratio of 1:20 and double-boiled for 30 minutes, left to cool and filtered through grade 4 Whatman filter paper. The hot aqueous extract was then freeze-dried at $-50^{\circ} \mathrm{C} \pm 2^{\circ} \mathrm{C}$ for 48 hours and stored at $4^{\circ} \mathrm{C}$ in airtight containers. The freeze-dried hot aqueous extract of the mycelia was used as the reducing and stabilizing agent for the reduction of $\mathrm{Ag}^{+}$to $\mathrm{Ag}^{0}$.

\section{Synthesis of AgNPs}

Synthesis of AgNPs was carried out according to a method described earlier. ${ }^{9}$ In a typical reaction, $1 \mathrm{mg} / \mathrm{mL}$ of freezedried hot aqueous mushroom mycelia extract was mixed with an aqueous solution of $1 \mathrm{mM} \mathrm{AgNO}_{3}$ solution and kept at room temperature for 24 hours. The synthesis was observed using ultraviolet (UV)-visible spectroscopy. The color change to reddish brown in the presence of silver nitrate took place within 12 hours.

\section{Characterization of AgNPs}

Characterization of AgNPs was carried out according to methods described previously. ${ }^{38}$ The prepared AgNPs were primarily characterized by UV-visible spectroscopy, which has proved to be a very useful technique for the analysis of AgNPs. UV-visible spectra were obtained using a Biochrom (Cambridge, UK) WPA Biowave II UV-visible spectrophotometer. The particle size of dispersions was measured by a Zetasizer Nano ZS90 (Malvern Instruments, Malvern, UK). X-ray diffraction (XRD) analyses were carried out on an X-ray diffractometer (D8 Discover; Bruker, Billerica, MA, USA). The high-resolution XRD patterns were measured at $3 \mathrm{~kW}$ with $\mathrm{Cu}$ target using a scintillation counter $(\lambda=1.5406 \AA)$ at $40 \mathrm{kV}$ and $40 \mathrm{~mA}$ were recorded in the range of $2 \theta=5^{\circ}-80^{\circ}$. Transmission electron microscopy (TEM; JEM-1200EX; JEOL, Tokyo, Japan) was used to determine the size and morphology of AgNPs. TEM images were obtained at an accelerating voltage of $300 \mathrm{kV}$.

\section{Cell culture}

MDA-MB-231 human breast cancer cells were kindly provided by Kyung Jin Lee, Institute for Life Sciences, ASAN Medical Center, University of Ulsan College of Medicine, Seoul, South Korea. MDA-MB-231 breast cancer cell lines were grown adherently and maintained in DMEM containing $10 \%$ fetal calf serum, and $1 \%$ antibiotic solution containing penicillin and streptomycin at $37^{\circ} \mathrm{C}$ in $5 \% \mathrm{CO}_{2}$. All experiments were performed in six-well plates, unless stated otherwise. Cells were seeded onto the plates at a density of 
$1 \times 10^{6}$ cells per well and incubated for 24 hours prior to the experiments. The cells were washed with phosphate-buffered saline (PBS; $\mathrm{pH} 7.4$ ) and incubated in fresh medium containing different concentrations of AgNPs dissolved in water.

\section{Cell-viability assay}

Cell viability was measured using the MTT (3-[4, 5-dimethylthiazol-2-yl]-2,5-diphenyltetrazolium bromide) dye-reduction assay to determine the cytotoxic effect of the AgNPs at various concentrations. Briefly, cells were plated onto 96-well flat-bottom culture plates with various concentrations of AgNPs $(0-10 \mu \mathrm{g} / \mathrm{mL})$. All cultures were incubated for 24 hours at $37^{\circ} \mathrm{C}$ in a humidified incubator. After 24 hours of incubation $\left(37^{\circ} \mathrm{C}, 5 \% \mathrm{CO}_{2}\right.$ in a humid atmosphere), $10 \mu \mathrm{L}$ of MTT ( $5 \mathrm{mg} / \mathrm{mL}$ in PBS) was added to each well, and the plate was incubated for a further 4 hours at $37^{\circ} \mathrm{C}$. The resulting formazan was dissolved in $100 \mu \mathrm{L}$ of dimethyl sulfoxide with gentle shaking at $37^{\circ} \mathrm{C}$, and absorbance was measured at $595 \mathrm{~nm}$ with an enzymelinked immunosorbent assay reader (SpectraMax; Molecular Devices, Sunnyvale, CA, USA). The results were given as the means of three independent experiments. Concentrations of AgNPs showing a 50\% reduction in cell viability (ie, half-maximal inhibitory concentration $\left[\mathrm{IC}_{50}\right]$ values) were then calculated. ${ }^{48,49}$

\section{Membrane integrity}

Cell-membrane integrity of MDA-MB-231 cells was evaluated as described earlier, ${ }^{48,49}$ by determining the activity of LDH leaking out of the cell according to the manufacturer's instructions (TOX7 in vitro toxicology assay kit; SigmaAldrich). The LDH assay is based on the release of the cytosolic enzyme LDH from cells with damaged cellular membranes. Thus, in cell culture, the course of AgNPinduced cytotoxicity was followed quantitatively by measuring the activity of LDH in the supernatant. Briefly, cells were exposed to various concentrations of AgNPs for 24 hours, and then $100 \mu \mathrm{L}$ per well of each cell-free supernatant was transferred in triplicate into wells in a 96-well plate, and $100 \mu \mathrm{L}$ of $\mathrm{LDH}$-assay reaction mixture was added to each well. After a 3-hour incubation under standard conditions, the optical density of the color generated was determined at a wavelength of $490 \mathrm{~nm}$ using a microplate reader.

\section{Determination of ROS}

Intracellular ROS were measured based on the intracellular peroxide-dependent oxidation of $2^{\prime}, 7^{\prime}$-dichlorodihydrofluore scein diacetate (DCFH-DA; Life Technologies) to form the fluorescent compound 2',7'-dichlorofluorescein (DCF), as previously described. ${ }^{49}$ Cells were seeded onto 24 -well plates at a density of $5 \times 10^{4}$ cells per well and cultured for 24 hours. After washing twice with PBS, fresh medium containing $6 \mu \mathrm{g} / \mathrm{mL}$ of AgNPs or $1 \mu \mathrm{M}$ doxorubicin was added, and the cells incubated for 24 hours. For the control, $20 \mu \mathrm{M}$ of DCFH-DA was added to the cells, and incubation continued for 30 minutes at $37^{\circ} \mathrm{C}$. The cells were rinsed with PBS, $2 \mathrm{~mL}$ of PBS was added to each well, and fluorescence intensity was determined with a spectrofluorometer (Gemini EM; Molecular Devices) with excitation at $485 \mathrm{~nm}$ and emission at $530 \mathrm{~nm}$. For the cells grown in 24-well plates for 24 hours, the antioxidant $N$-acetyl-L-cysteine (NAC; $5 \mathrm{mM}$ ) was added for 1 hour prior to exposing them to $6 \mu \mathrm{g} / \mathrm{mL}$ AgNPs or $1 \mu \mathrm{M}$ doxorubicin for 12 hours. DCFH-DA $(20 \mu \mathrm{M})$ was then added and the cells incubated for $30 \mathrm{~min}$ at $37^{\circ} \mathrm{C}$ before measuring changes of DCF fluorescence.

\section{Measurement of caspase- 3 activity}

The cells were treated with $6 \mu \mathrm{g} / \mathrm{mL} \mathrm{AgNPs}$, purified caspase 3, or caspase- 3 inhibitor for 24 hours. The activity of caspase 3 was measured in MDA-MB-231 cells using a kit from Sigma-Aldrich, according to the manufacturer's instructions. Cells were washed with ice-cold PBS and lysed with $100 \mu \mathrm{L}$ of lysis buffer (50 mM Tris- $\mathrm{HCl}$ [pH 7.5], $150 \mathrm{mM} \mathrm{NaCl}, 1 \mathrm{mM}$ ethylene glycol tetraacetic acid, $1 \mathrm{mM}$ NaF, $1 \%$ Nonidet P-40, and $1 \mathrm{mM}$ phenylmethanesulfonylfluoride protease-inhibitor cocktail) for 30 minutes at $4^{\circ} \mathrm{C}$. Protein extracts were collected after centrifugation at $14,000 \mathrm{rpm}$ for 10 minutes. Protein concentration was determined using a Bio-Rad protein assay kit (Bio-Rad Laboratories, Hercules, CA, USA). Equal amounts $(50 \mu \mathrm{g})$ of protein extracts were mixed with assay buffer $(20 \mathrm{mM}$ 4-[-hydroxyethyl]-1-piperazineethanesulfonic acid [pH 7.4], $100 \mathrm{mM} \mathrm{NaCl}, 0.1 \%$ CHAPS (3-[(3-cholamidopropyl) dimethylammonio]-1-propanesulfonate), $10 \mathrm{mM}$ dithiothreitol (DTT), $1 \mathrm{mM}$ EDTA, 10\% sucrose), added to 96 well microtiter plates, and incubated with the caspase-3 substrate acetyl-Asp-Glu-Val-Asp p-nitroanilide (Ac-DEVD-pNA) and a caspase- 3 inhibitor (Ac-DEVD-CHO) for 1 hour, and the absorbance read at $405 \mathrm{~nm}$. The calorimetric assay is based on the hydrolysis of caspase-3 substrate by caspase 3 , resulting in the release of the pNA moiety. The concentration of the pNA released from the substrate is calculated from the absorbance values at $405 \mathrm{~nm}$. The assay was done with noninduced cells and also in the presence of the 
caspase-3 inhibitor (Ac-DEVD-CHO) for a comparative analysis.

\section{DNA-fragmentation assay}

MDA-MB-231 ( $10^{6}$ cells $\left./ \mathrm{mL}\right)$ were seeded in six-well microplates and treated with $6 \mu \mathrm{g} / \mathrm{mL}$ of AgNPs. After 24 hours of treatment, the culture medium was removed and the cells harvested by scraping with $1 \mathrm{~mL}$ of PBS and lysed with $500 \mu \mathrm{L}$ of lysis buffer (20 mM Tris-HCl [pH 8.0], $5 \mathrm{mM}$ EDTA, $400 \mathrm{mM} \mathrm{NaCl}, 1 \%$ sodium dodecyl sulfate, and $10 \mathrm{mg} / \mathrm{mL}$ proteinase $\mathrm{K}$ ) for 1 hour at $55^{\circ} \mathrm{C}$. Fragmented DNA was extracted with phenol/chloroform/isoamyl alcohol $(25: 24: 1 \mathrm{v} / \mathrm{v} / \mathrm{v})$, precipitated with ethanol, and resuspended in Tris-EDTA buffer (TE, pH 8.0) containing $20 \mu \mathrm{g} / \mathrm{mL}$ RNase A. For quantitative analyses of DNA content, an equal amount of DNA was loaded and run on a 1.0\% agarose gel containing $1 \mu \mathrm{g} / \mathrm{mL}$ ethidium bromide at $80 \mathrm{~V}$, and the DNA fragments were visualized by exposing the gel to UV light, followed by photography.

\section{Detection of apoptosis by TUNEL assay}

Apoptotic DNA fragmentation was also detected by using a DNA fragmentation imaging kit (Roche, Basel, Switzerland), following the manufacturer's instructions. Based on the terminal deoxynucleotidyl transferase deoxyuridine triphosphate nick-end labeling (TUNEL) reaction, fluorescence detection of cells with apoptotic DNA strand breaks was performed. To examine total cell numbers, nuclei were labeled simultaneously with 4',6-diamidino-2phenylindole. Merged images of both channels were shown using a fluorescence microscope (Olympus, Tokyo, Japan) at $100 \times$ magnification.

\section{Results and discussion Extracellular synthesis of AgNPs}

In this study, we attempted to use the extract of G. neo-japonicum for synthesis of AgNPs. Shown in Figure 1 are tubes with the silver nitrate, G. neo-japonicum mycelial extract, and extract after reaction with $\mathrm{Ag}^{+}$ions for 24 hours. It was observed that the extract had a pale-yellow color before reaction with the silver ions, which changed to a brownish color on completion of the reaction. The appearance of a yellowish-brown color in solution containing the extract was a clear indication of the formation of AgNPs in the reaction mixture, and was due to the excitation of surface plasmon vibrations in the NPs. ${ }^{14,50,51}$ The color change indicates that G. neo-japonicum mycelial extract could be used as a

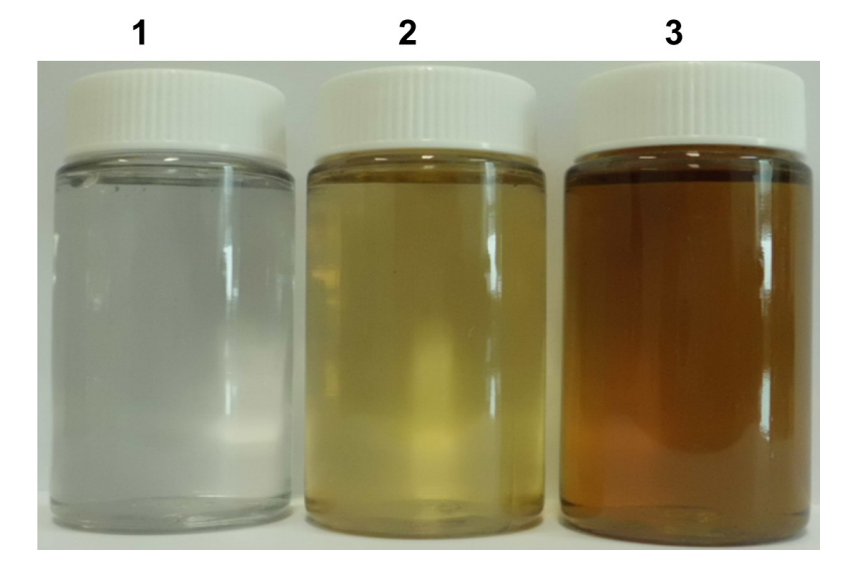

Figure I Synthesis of silver nanoparticles (AgNPs) using Ganoderma neo-japonicum extract. The photo shows containers with samples of $\mathrm{AgNO}_{3}$ (I), G. neo-japonicum mycelia extract (2), $\mathrm{AgNO}_{3}$ with the $\mathrm{G}$. neo-japonicum mycelia extract (3). After exposure for 24 hours the color of the solution turned from colorless to brown, indicating the formation of AgNPs.

reducing and stabilizing agent for AgNP synthesis, and also it serves as a piece of evidence for synthesis of AgNPs.

\section{Characterization of AgNPs using UV-visible spectroscopy}

Further, the prepared AgNPs were characterized by UVvisible spectroscopy. UV-visible spectroscopy is an important and valuable technique for the characterization of NPs. ${ }^{50}$ The UV-visible absorption spectra of the AgNPs were measured in the range of 300-600 $\mathrm{nm}$. A strong and broad surface plasmon peak located at $420 \mathrm{~nm}$ was observed for the AgNPs prepared using mycelia extract of G. neo-japonicum (Figure 2). The strong surface plasmon resonance centered at $420 \mathrm{~nm}$ clearly indicates the formation of AgNPs, which were extremely stable, with no evidence of flocculation of the particles even after 3 months. ${ }^{14}$ The band around $420 \mathrm{~nm}$ suggests that the particles were well dispersed without aggregation. The long-term stability of the NP solution may be due to the proteins in the mushroom extract as capping agents. ${ }^{14}$ Further, we examined the function of time for the synthesis of AgNPs, and the results suggest that the intensity of this peak steadily increases with an increase in the reaction time, which may be attributed to the formation of AgNPs with the progress of the reaction, because the intensity of the surface plasmon peak is directly proportional to the density of the NPs in solution. Maximum intensity was achieved after 24 hours of the reaction, which indicates the complete reduction of the $\mathrm{Ag}^{+}$ions. An intense brown color of the reaction mixture further supports the complete reduction of $\mathrm{Ag}^{+}$ions and the formation of AgNPs. ${ }^{7,8,19}$ 


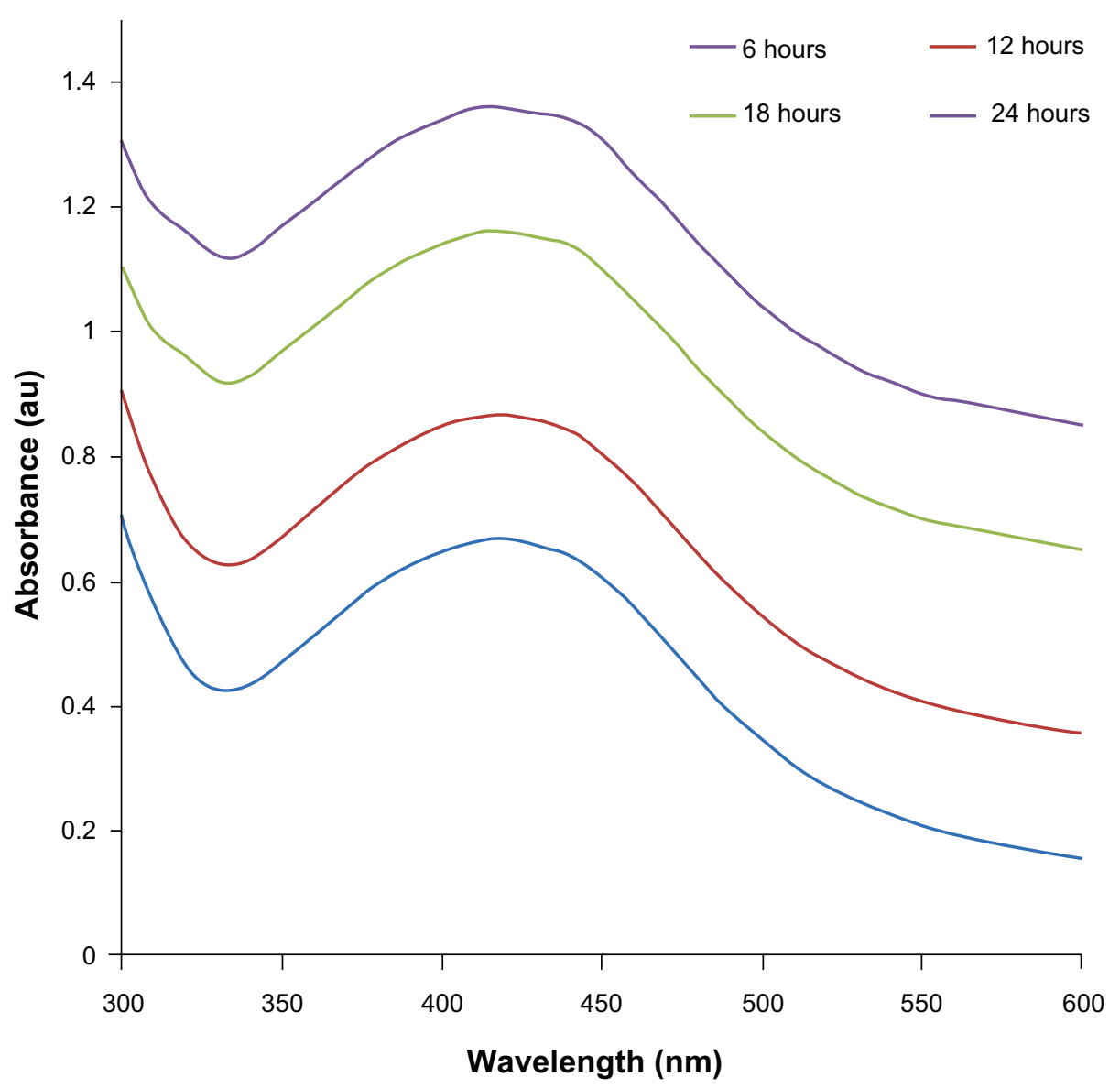

Figure 2 The ultraviolet-visible spectra of silver nanoparticles (AgNPs). The absorption spectra of AgNPs exhibited a strong broad peak at $420 \mathrm{~nm}$, and observation of this band was attributed to surface plasmon resonance of the particles.

\section{XRD analysis of AgNPs}

Next, we examined the confirmation of the crystalline nature of AgNPs using XRD. Figure 3 shows the XRD pattern obtained for AgNPs synthesized using the mycelia extract of G. neo-japonicum. Regarding the crystalline nature of the AgNPs, two intense XRD peaks were observed, corresponding to the (111) and (200) planes at $2 \theta$ angles of $38.28^{\circ}$ and $44.38^{\circ}$, respectively (Figure 3 ). XRD spectra of the nanoparticles derived from G. neo-japonicum extract suggest the formation of metallic silver. The width of the (111) peak was employed to calculate the average crystallite size using the Scherrer equation. It was found that the calculated average size is $<6 \mathrm{~nm}$, which matches the particle size obtained from a TEM image of AgNPs using Ganoderma extract. In addition to the Bragg peaks representative of face-centered cubic AgNPs, additional as-yet-unassigned peaks (marked with stars) were also observed, suggesting that the crystallization of the bioorganic phase occurred on the surface of the AgNPs. Our results represent a significant consensus with earlier findings reporting synthesis of AgNPs using geranium leaf extracts and edible mushroom extract. ${ }^{52,53}$ However, the Vikneswaran et $\mathrm{a}^{25}$ suggested an intense diffraction peak at $2 \theta$ angles of $57.3^{\circ}$, due to the chloride ions involved during the preparation of the cell filtrate, and also possibly due to residue from an extract of the biomass. ${ }^{24,25}$ In addition, three new peaks were formed due to the interaction of silver nitrate with the fungal cell-wall matrix. ${ }^{25}$

\section{Size-distribution analysis by dynamic light scattering}

To know the average size of synthesized AgNPs, a sizedistribution analysis was performed using dynamic light scattering (DLS) in aqueous solution. Figure 4 shows that the average particle size of G. neo-japonicum extract prepared AgNPs was $5 \mathrm{~nm}$. DLS results showed the size ranging between 2 and $10 \mathrm{~nm}$ and a low polydispersity index of 0.175 , indicating that a monodisperse distribution of mostly single and uniform size of species was present in solution. Mukherjee et al ${ }^{54}$ demonstrated that exposure of an aqueous $\mathrm{AgNO}_{3}$ solution to the fungus Verticillium caused 


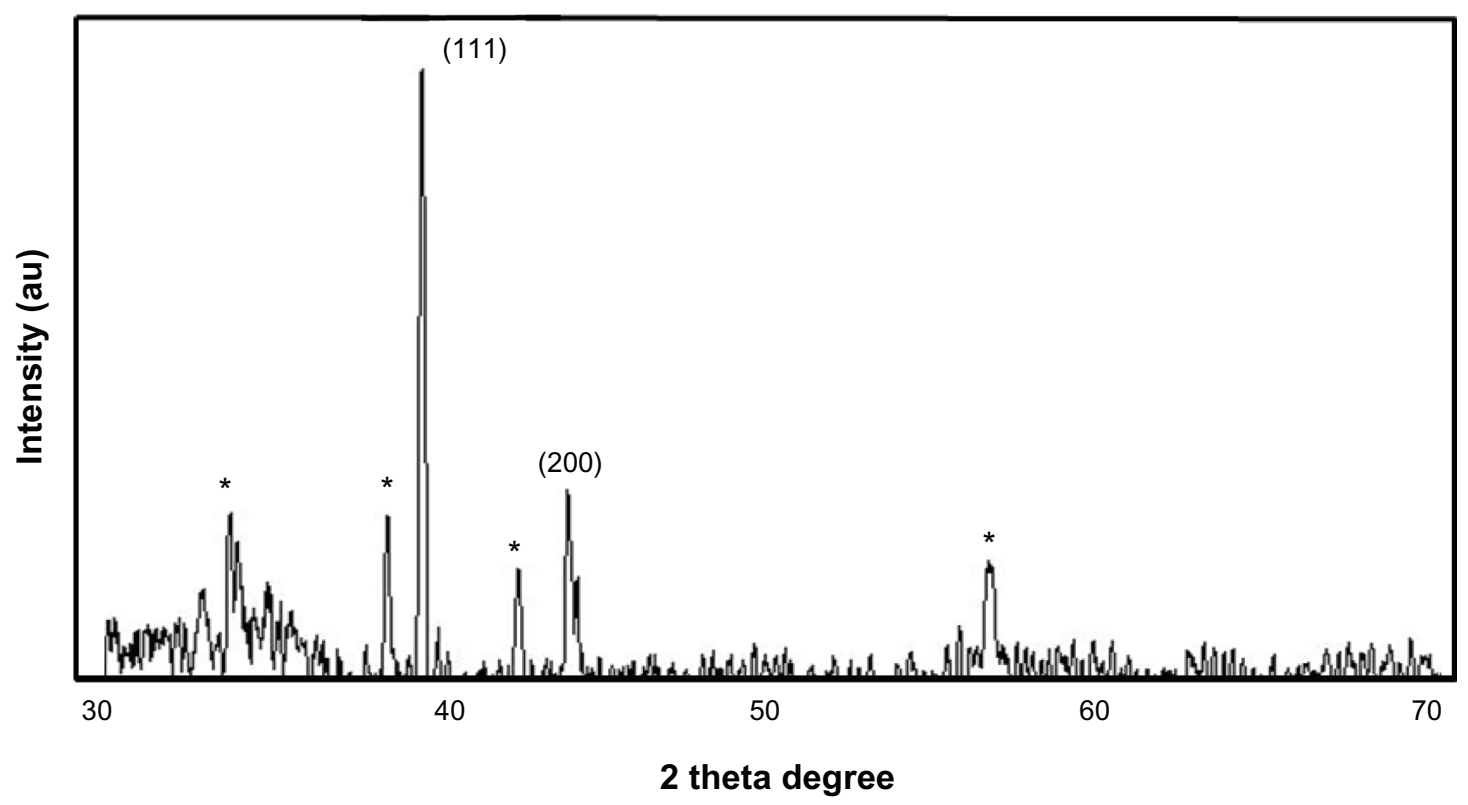

Figure 3 X-ray diffraction pattern of the silver nanoparticles (AgNPs) derived from Ganoderma neo-japonicum mycelial extract. The diffractions at $38.28^{\circ}$ and $44.38^{\circ} 2 \theta$ can be indexed to the (III) and (200) planes of the face-centered cubic AgNPs, respectively.

Note: The stars indicate the nonspecific peaks due to biomass residues.

the reduction of the metal ions and formation of AgNPs of $25 \mathrm{~nm}$ diameter. ${ }^{13}$ The cell-associated biosynthesis of AgNPs were reported in F. oxysporum, and the particles were quasispherical overall with a size range between 5 and $15 \mathrm{~nm} .{ }^{14}$

\section{Size and morphology analysis of AgNPs by transmission electron microscopy}

To verify the data derived from DLS analysis, further characterization of AgNPs was done using TEM to examine

Diameter $(\mathrm{nm})$

Width (nm)

Z-average (dnm: 5.0)

PDI: 0.175

$\begin{array}{lll}\text { Peak 1 } & 4.4 & 2.0 \\ \text { Peak 2 } & 0.000 & 0.000 \\ \text { Peak 3 } & 0.000 & 0.000\end{array}$

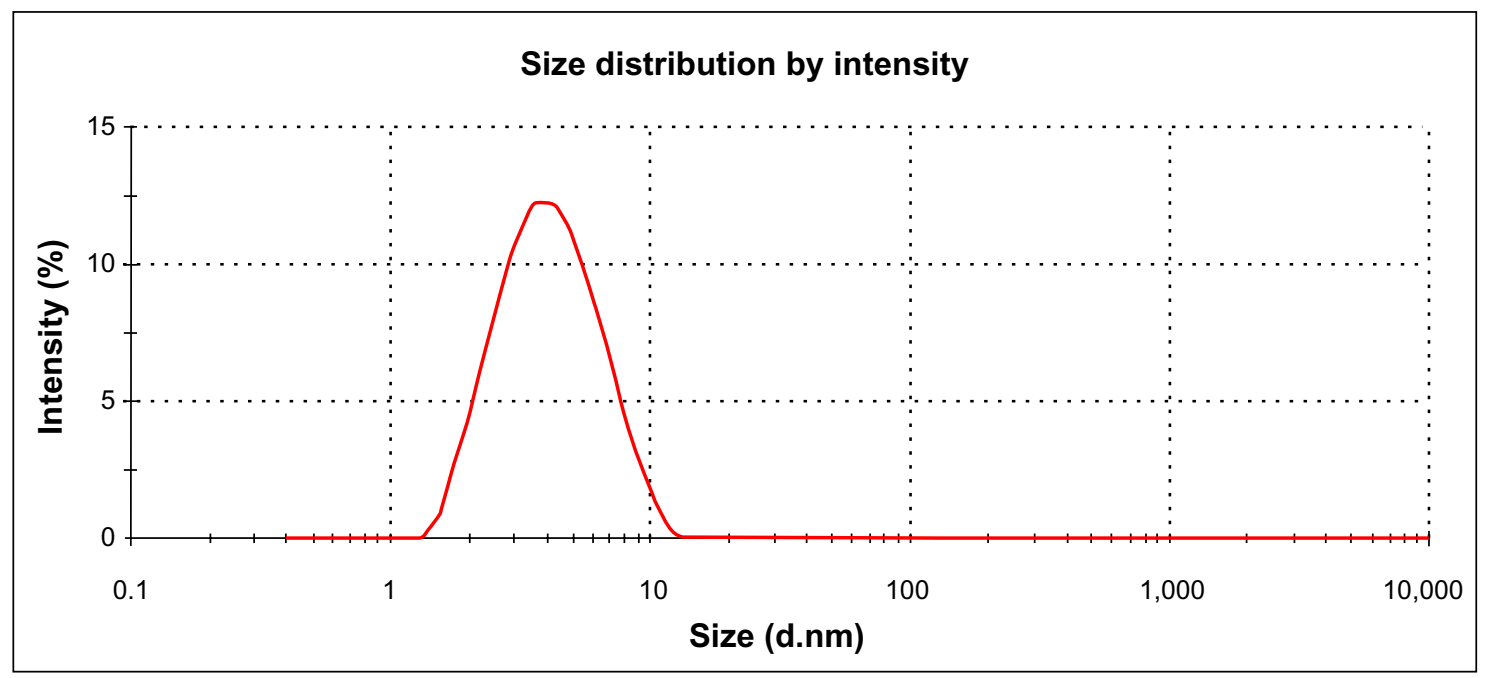

Figure 4 Size-distribution analysis by dynamic light scattering. The particle size-distribution analysis revealed that particle size was about $5 \mathrm{~nm}$. Abbreviations: dnm, diameter; PDI, polydispersity index. 
their size and morphology. The representative TEM image is shown in Figure 5, and indicates well-dispersed particles that are significantly uniform and spherical. The TEM analysis revealed that the average size of the particles synthesized by G. neo-japonicum was approximately 5-8 nm. A significant proportion of largely spherical AgNPs within the range of $5 \mathrm{~nm}$ were observed in TEM micrographs. The spherical particles were reasonably uniform in size and in agreement with DLS data. Overall analysis of DLS and TEM suggests that the average size of AgNPs derived from Ganoderma spp. mushroom extract was $5 \mathrm{~nm}$. Vigneshwaran et al ${ }^{55}$ reported that the average size of AgNPs using spent mushroom substrate was $30.5 \mathrm{~nm}$. The average size of AgNPs using edible mushroom Pleurotus florida and Volvariella volvacea was $20 \pm 5 \mathrm{~nm}$ and $15 \mathrm{~nm}$, respectively. ${ }^{17,18}$ The G. neo-japonicum-synthesized NPs revealed polydispersity and sizes between 10 and $70 \mathrm{~nm}$, with an average size of $45 \mathrm{~nm} .^{21}$ In general, smaller NPs have significant toxicity in bacteria when compared to larger ones. Reducing the particle size of materials is an efficient and reliable tool for improving their biocompatibility. ${ }^{56}$

\section{AgNP-induced cytotoxicity in MDA-MB-23I breast cancer cells}

The cell-viability assay is one of the important parameters for toxicology analysis that explains the cellular responses to toxic materials, and it can provide information on cell death, survival, and metabolic activities. ${ }^{39}$ To examine

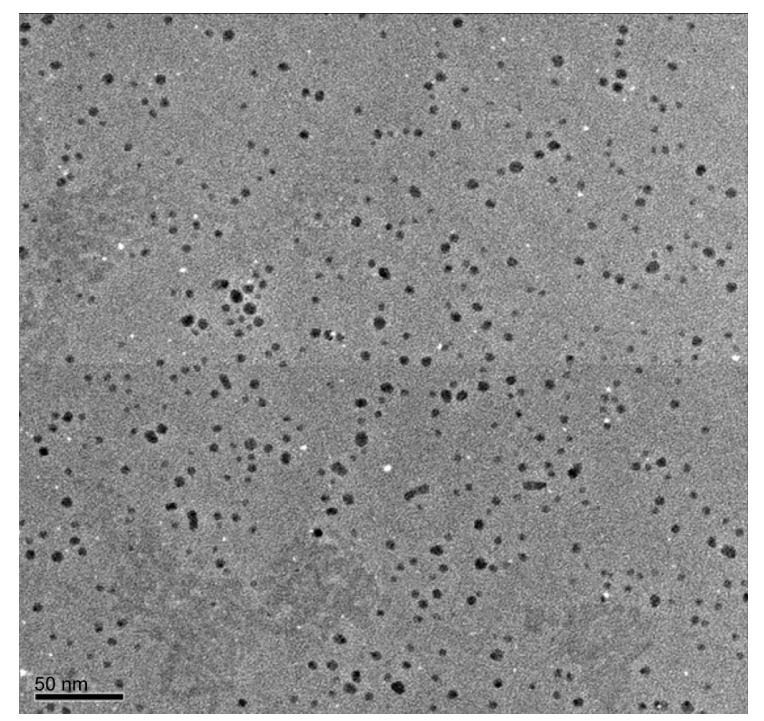

Figure 5 Size and morphology of silver nanoparticle (AgNP) analysis by transmission electron microscopy (TEM).

Notes: Several fields were photographed and used to determine the diameter of the NPs. Representative TEM image of AgNPs produced by Ganoderma neo-japonicum mycelial extract. The maximum size of the observed diameter was $5 \mathrm{~nm}$. the effect of AgNPs on mitochondrial activity, cells were treated with various concentrations of AgNPs between 1 and $10 \mu \mathrm{g} / \mathrm{mL}$, and toxicity was measured. The data from this experiment suggest that higher concentrations between 6 and $10 \mu \mathrm{g} / \mathrm{mL}$ had significantly more impact on cell viability than 1-4 $\mu \mathrm{g} / \mathrm{mL}$. At 24 hours of treatment, AgNPs were found to be significantly toxic to the cells at concentrations of $6 \mu \mathrm{g} / \mathrm{mL}$ and higher (Figure 6). AgNP-treated cells showed decreased metabolic activity, which depends on the nature of cell types and the size of NPs. ${ }^{57}$ Franco-Molina et al ${ }^{32}$ reported a colloidal silver-induced dose-dependent cytotoxic effect on MCF-7 breast cancer cells. The rate of cell viability was significantly reduced as a function of both culture time and AgNP concentration in human IMR-90 and U251 cells, mouse embryonic stem cells, and A549 lung cells. ${ }^{39}$ Gopinath et $\mathrm{al}^{58}$ found that the $\mathrm{IC}_{50}$ value of $\mathrm{AgNPs}$ prepared using chemical methods with a size of $10-15 \mathrm{~nm}$ was $27.0 \mu \mathrm{g} / \mathrm{mL}$ in BHK21 (noncancer) and HT29 (cancer) cells and higher concentrations of AgNPs $(>44.0 \mu \mathrm{g} / \mathrm{mL})$ became necrotic to cells, leading to rapid cell-membrane rupture. ${ }^{59}$ Dosedependent cytotoxicity of $\mathrm{AgNPs}$ and $\mathrm{AgNO}_{3}$ was observed in human Chang liver cells, the results indicating that AgNPs showed significantly higher cytotoxicity than $\mathrm{AgNO}_{3} \cdot{ }^{58} \mathrm{In}$ our experiment, the cell-proliferation assay suggested that the $\mathrm{IC}_{50}$ was $6.0 \mu \mathrm{g} / \mathrm{mL}$, which is significantly better than earlier findings. However, the action of AgNPs depends on size, shape, conditions of media, type of cells, and also dose- and time-dependence.

\section{Impact of AgNPs on membrane integrity}

LDH is a characteristic marker for cell death. LDH assay can be used to determine the status of cells under a given condition. We examined the effect of various concentrations of AgNPs on membrane integrity; the cells were treated with various concentrations of AgNPs for 24 hours. The results suggest that cell-membrane leakage was dose-dependent and significantly affected (Figure 7). The results from the LDH assay were consistent with cell viability; with increasing concentrations of AgNPs, the cells became gradually more cytotoxic. The increase of LDH leakage was due to abrupt cell-membrane lysis consequently leading to cell death, which suggest that the membrane leakage was a consequence of the apoptosis. Similarly, Hussain et al ${ }^{60}$ demonstrated that exposure to AgNPs for 24 hours resulted in a concentration-dependent increase in LDH leakage and exhibited significant cytotoxicity at $10-50 \mu \mathrm{g} / \mathrm{mL}$ in BRL $3 \mathrm{~A}$ rat liver cells. Park et $\mathrm{al}^{57}$ analyzed the status of LDH leakage in L929 fibroblasts with various sizes of AgNPs, 


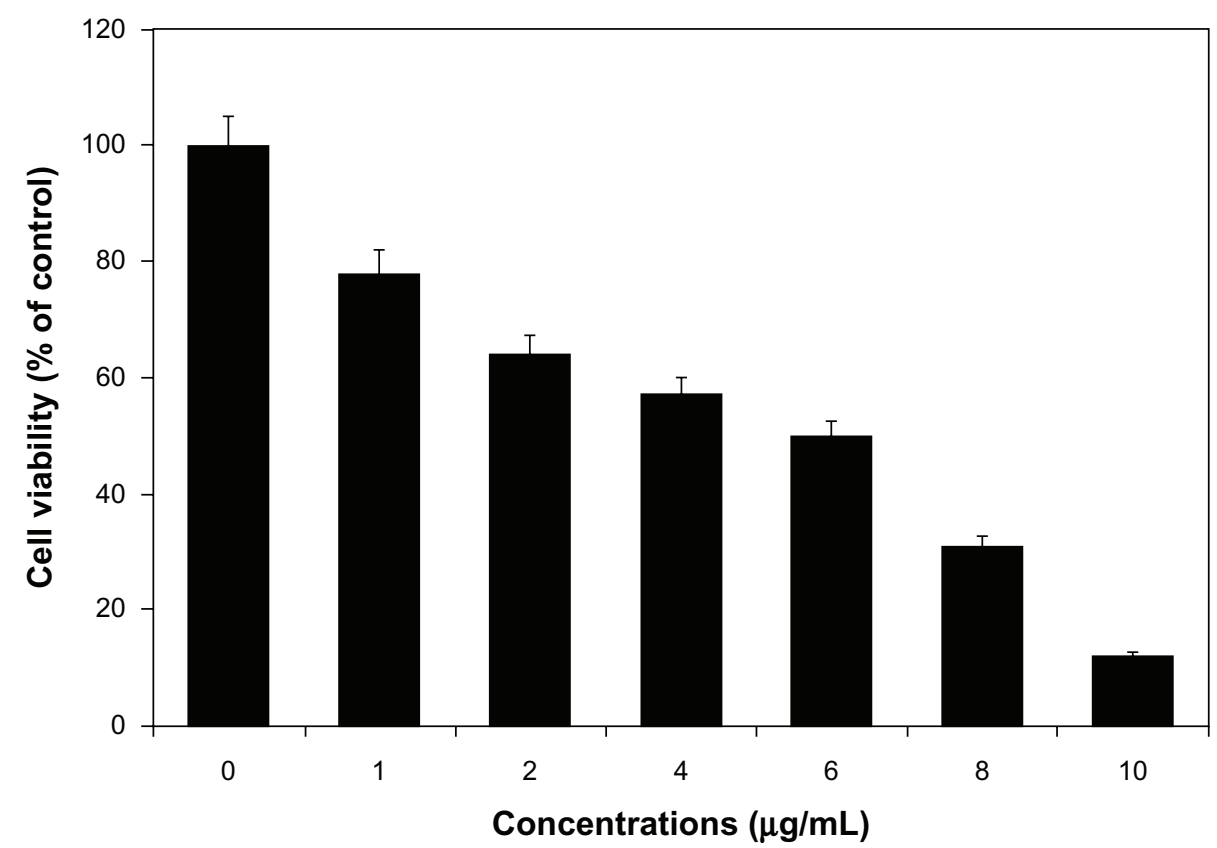

Figure 6 Cytotoxic effect of silver nanoparticles (AgNPs) on MDA-MB-23I human breast cancer cells. Cells were treated with AgNPs at various concentrations for 24 hours, and cytotoxicity was determined by the MTT (3-[4,5-dimethylthiazol-2-yl]-2,5-diphenyltetrazolium bromide) method.

Notes: The results represent the means of three separate experiments, and error bars represent the standard error of the mean. Treated groups showed statistically significant differences from the control group with Student's $t$-test $(P<0.05)$.

and the results suggested that cell-membrane integrity was significantly affected. Enzymes secreted into the media for all three different sizes of AgNP-treated samples, among which $20 \mathrm{~nm}$ AgNPs were more effective than the 80 and $113 \mathrm{~nm}$ ones. Water-soluble mPEG-SH-coated AgNPs decreased cell viability in dose- and time-dependent manners and decreased the activities of superoxide dismutase and glutathione peroxides ${ }^{61}$ Lee et al ${ }^{62}$ observed that the LDH level increased $210 \%$ when cells were cultivated for 48 hours in a culture medium containing AgNPs at $100 \mu \mathrm{g} / \mathrm{mL}$, and found that

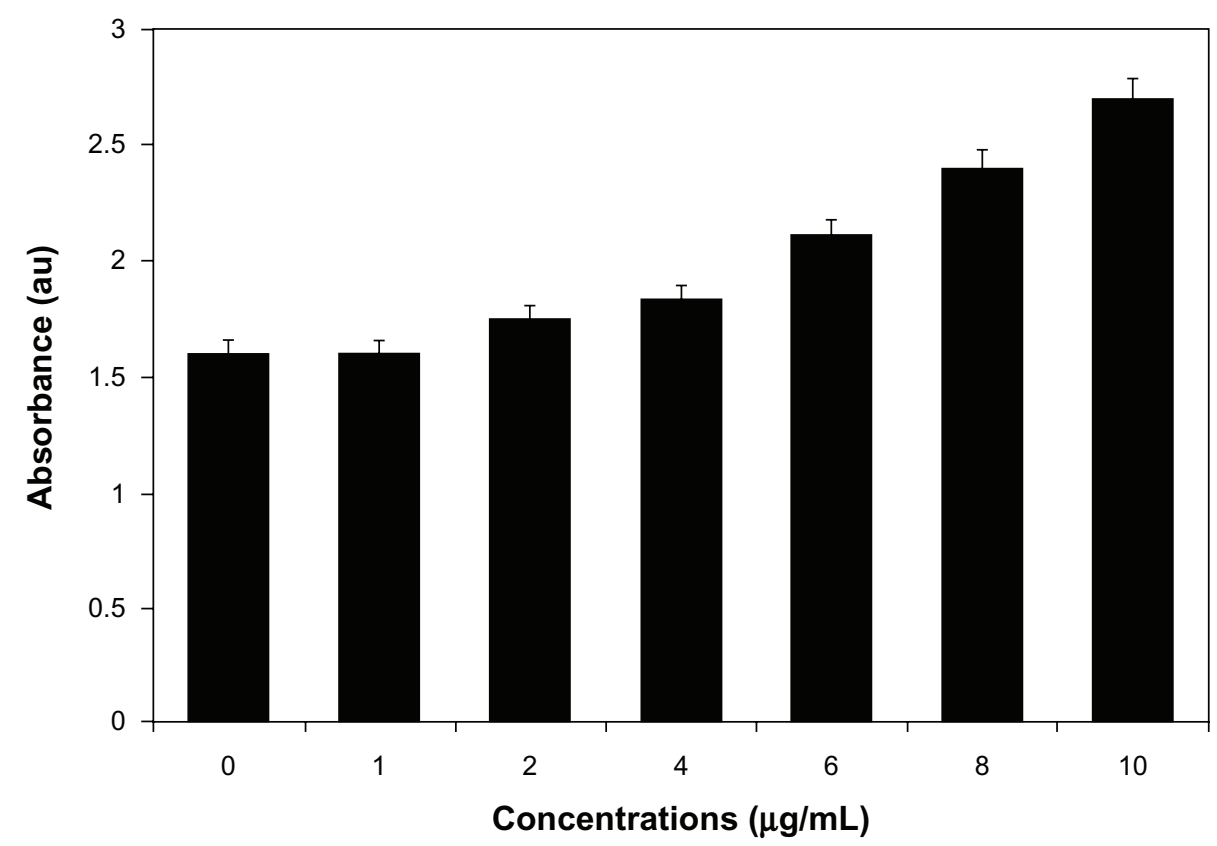

Figure 7 Effect of silver nanoparticles (AgNPs) on lactate dehydrogenase activity in MDA-MB-23I human breast cancer cells.

Notes: The cells were treated with various concentrations of AgNPs. The effect of AgNPs on lactate dehydrogenase activity was measured by changes in optical densities due to nicotinamide adenine dinucleotide (NAD) reduction that were monitored at $490 \mathrm{~nm}$, using Roche's cytotoxicity detection lactate dehydrogenase kit. The results represent the means of three separate experiments, and error bars represent the standard error of the mean. Treated groups showed statistically significant differences from the control group with Student's $t$-test $(P<0.05)$. 
AgNPs could induce the release of LDH in a concentrationand time-dependent manner, indicating that AgNPs reduced the membrane potential in A549 cells. We found that an $\mathrm{IC}_{50}$ concentration of $6.0 \mu \mathrm{g} / \mathrm{mL}$ was significant to inhibit cell growth and sufficient to induce cell death. Therefore, this concentration was used for further analysis.

\section{AgNP-induced oxidative stress in MDA- MB-23I human breast cancer cells}

Several studies have provided strong evidence for a link between AgNP-mediated production of ROS and subsequent generation of oxidative stress and cytotoxicity. Oxidative stress in turn plays an important role in many types of cellular injury, which can result in DNA damage and apoptotic cell death. ${ }^{63-68}$ ROS are chemical species that are produced as by-products of cellular oxygen metabolism, which occurs via mitochondrial respiration in eukaryotic cells. ${ }^{63-68}$ AgNPs are capable of producing ROS. Abnormal accumulation of ROS is called oxidative stress, and can lead to serious cellular damage. ${ }^{63-71}$ According to a literature survey, currently there is limited information available about the mechanism of AgNP-induced toxicity. To know the effect of AgNPs on oxidative stress, we measured ROS generation using the $\mathrm{H}_{2}$ DCF-DA assay. AgNP-induced intracellular ROS generation was evaluated using intracellular peroxide-dependent oxidation of DCFH-DA to form fluorescent DCF. Cells were also treated with doxorubicin $1 \mu \mathrm{M}$ as a positive control.
DCF fluorescence was detected in cells treated with AgNPs for 24 hours. We examined ROS generation, which is considered to be a crucial component of apoptosis in many studies. Consistent with an increase in intracellular ROS, the level of ROS generation was markedly increased in AgNP-treated cells (Figure 8). These results indicate that ROS induced by AgNPs is a significant factor for apoptosis in yeast cells. To demonstrate that NAC acts as an $\mathrm{OH}$ scavenger, we also treated cells exposed to AgNPs with NAC. NAC significantly reduced the level of ROS generation in AgNP-treated cells. As shown in Figure 8, the ROS levels generated in response to AgNP- and doxorubicin-treated cells were significantly higher than the control. Consistent with earlier findings, all of the cytotoxic effects induced by AgNPs were efficiently prevented by NAC pretreatment (Figure 8), suggesting that the intrinsic toxicity of AgNPs is associated with oxidative damage-dependent pathways. ${ }^{71}$ The results derived from this experiment suggest that cell death is mediated by ROS production, which might alter the cellular redox status and be a potential reason for cell death. ${ }^{63-71}$

\section{AgNP-induced caspase-3 activation}

Several studies have been reported using various kinds of cultured cells and animal models to provide evidence for AgNP-induced genotoxicity and apoptosis. Apoptosis is well recognized as a distinctive mode of programmed cell death that involves the genetically determined elimination of

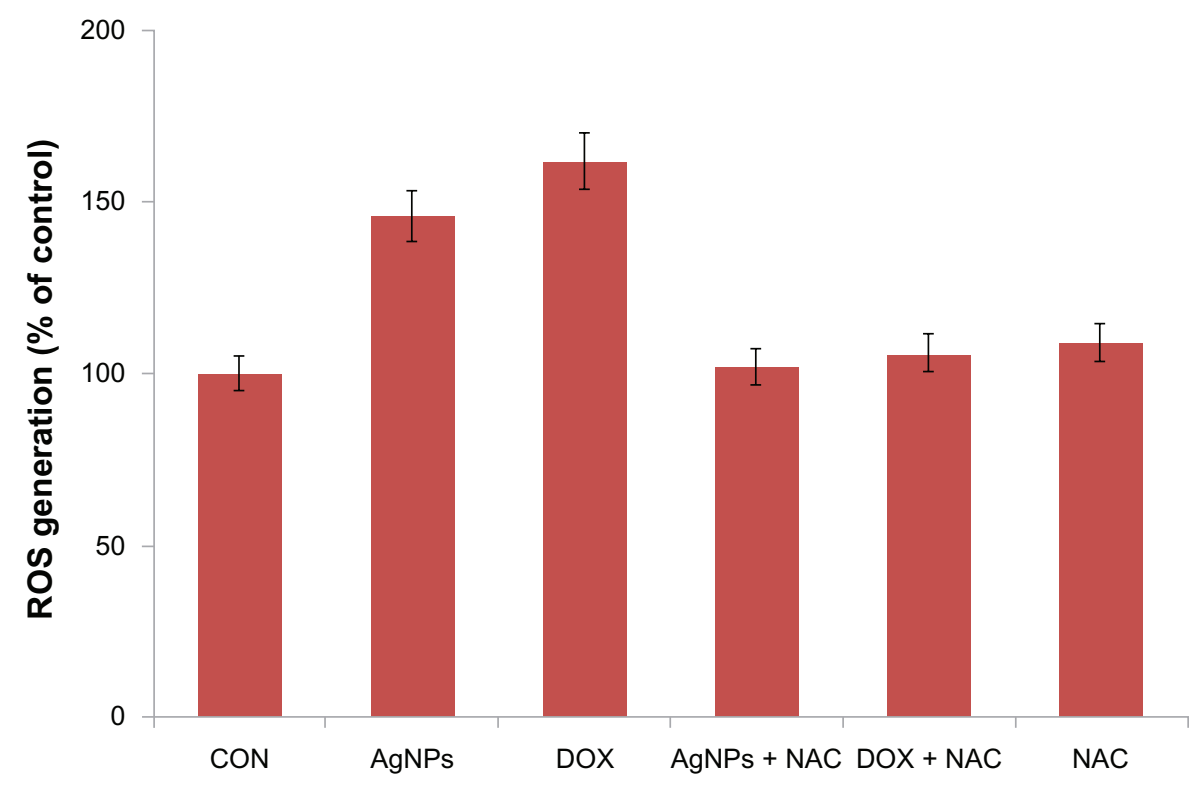

Figure 8 Silver nanoparticles (AgNPs) induce reactive oxygen species (ROS) generation in MDA-MB-23I human breast cancer cells. Relative fluorescence of 2',7'-dichlorofluorescein was measured using a spectrofluorometer with excitation at $485 \mathrm{~nm}$ and emission at $530 \mathrm{~nm}$.

Notes: The results represent the means of three separate experiments, and error bars represent the standard error of the mean. Treated groups showed statistically significant differences from the control $(\mathrm{CON})$ group with Student's $t$-test $(P<0.05)$.

Abbreviations: DOX, doxorubicin; NAC, $N$-acetyl-L-cysteine. 


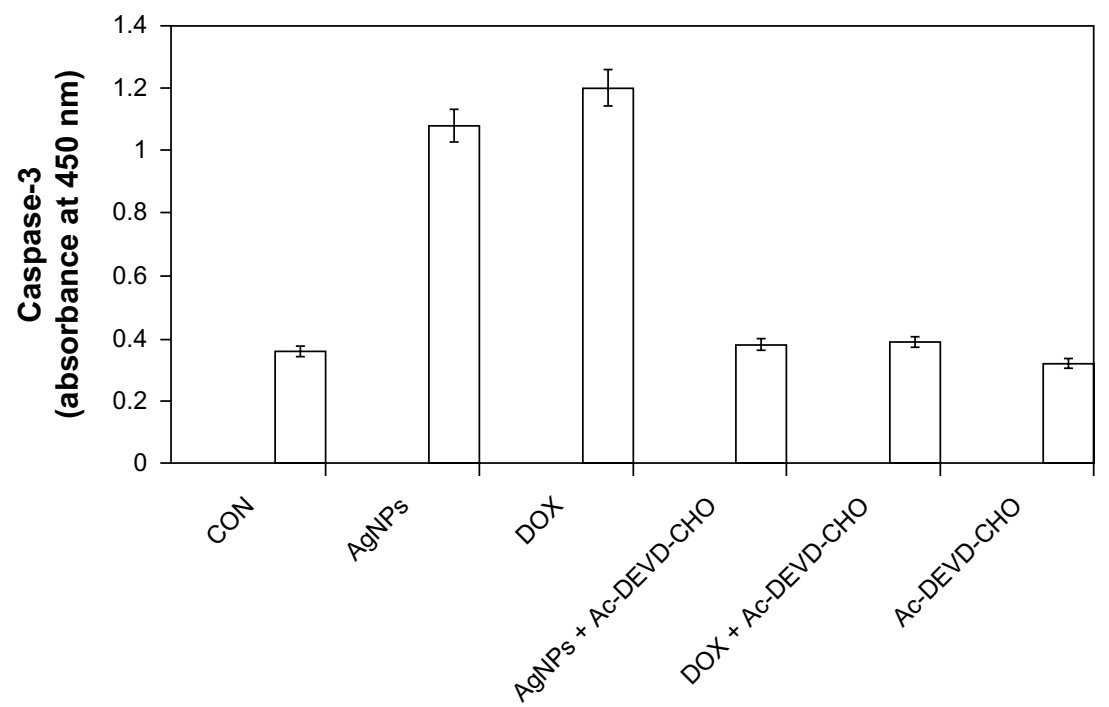

Figure 9 Silver nanoparticles (AgNPs) induce the activity of caspase 3 in MDA-MB-23I human breast cancer cells. MDA-MB-23I cells were treated with AgNPs, doxorubicin (DOX), and/or a caspase-3 inhibitor (Ac-DEVD-CHO) for 24 hours.

Notes: The concentration of the p-nitroaniline released from the substrate was calculated from the absorbance values at $405 \mathrm{~nm}$. The results represent the means of three separate experiments, and error bars represent the standard error of the mean. Treated groups showed statistically significant differences from the control group with Student's $t$-test $(P<0.05)$.

Abbreviation: CON, control.

cells. ${ }^{67}$ Proteolytic enzymes, such as caspases, are important effector molecules in apoptosis. Activation of caspases in response to environmental toxicants can be initiated through stimulation of the extrinsic pathway or the intrinsic pathway. ${ }^{67,68}$ Oxidative stress plays an important role in a variety of normal biochemical functions, and abnormality in these functions results in pathological processes. Excessive production of ROS in the cell is known to induce apoptosis. ${ }^{72}$ The caspase-3-activation cascade plays an important role in several apoptotic mechanisms. ${ }^{73}$ To know the effect of caspase- 3 activation induced by AgNPs, the cells were treated with AgNPs, and caspase- 3 activation suggested that AgNPs caused cell death through apoptosis. ${ }^{43}$ Figure 9 depicts the increase in the levels of caspase 3 during treatment with AgNPs as well as doxorubicin. Cells treated with a caspase- 3 inhibitor revealed a level of caspase-3 activation equal to control, which clearly indicates that caspase-3 plays a key role in the apoptotic pathway of cells. The increased level of caspase-3 activation in AgNP-treated cells could contribute to cell death through apoptosis. These results suggest that AgNPs induce apoptosis in breast cancer cells in a caspase-3-dependent manner. ${ }^{43}$

\section{DNA fragmentation}

Cellular DNA damage can result from the action of endogenous ROS or stochastic errors in replication or recombination, as well as from environmental toxicants. ${ }^{68}$ Several studies reported that AgNPs could alter many biochemical and

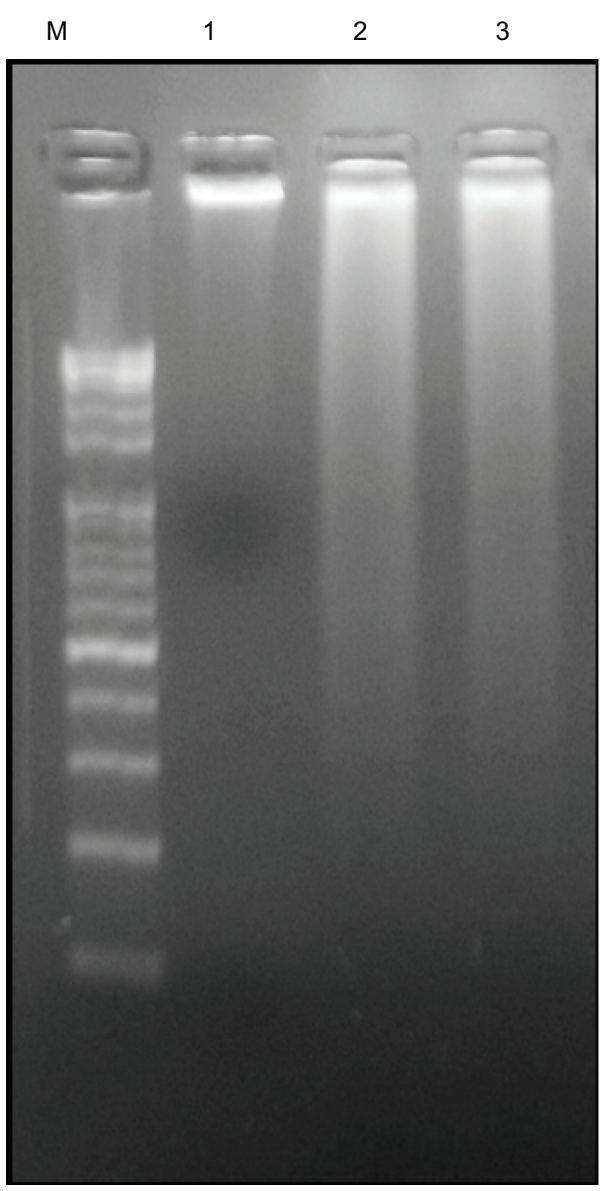

Figure 10 Effect of silver nanoparticles (AgNPs) on DNA fragmentation. MDAMB-23I human breast cancer cells were treated with AgNPs for 24 hours, and DNA fragmentation was analyzed by agarose gel electrophoresis.

Notes: Lane M, I kB ladder; lane I, control; lane 2, AgNPs $(6 \mu \mathrm{g} / \mathrm{mL})$; lane 3, doxorubicin ( $\mathrm{I} \mu \mathrm{M})$. 


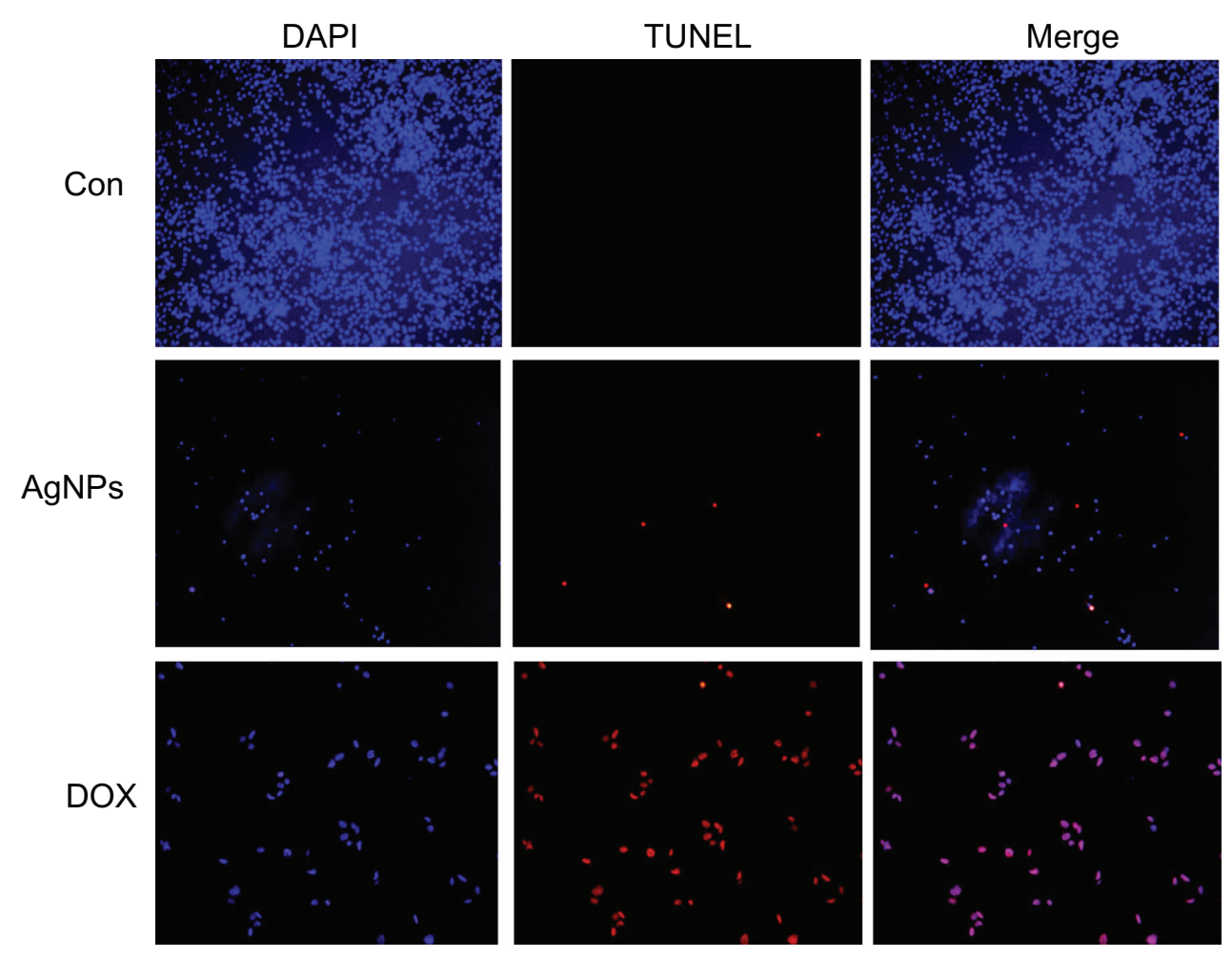

Figure I I Terminal deoxynucleotidyl transferase deoxyuridine triphosphate nick-end labeling (TUNEL) assay. Fluorescent staining of MDA-MB-23I human breast cancer cells after 24 hours' treatment with silver nanoparticles (AgNPs; $6 \mu \mathrm{g} / \mathrm{mL}$ ) and doxorubicin (DOX; I $\mu \mathrm{M})$ using TUNEL assay.

Note: Representative images are shown for apoptotic DNA fragmentation (red staining) and corresponding nuclei (blue staining).

Abbreviations: CON, control; DAPI, 4',6-diamidino-2-phenylindole.

molecular changes in cultured cells. AgNP-induced DNA breakage was detected in cell lines using the DNA comet assay. ${ }^{69}$ DNA laddering is a valuable technique to analyze the endonuclease cleavage products of apoptosis. The ROS can act as signal molecules promoting cell-cycle progression, and can induce oxidative DNA damage. ${ }^{74}$ DNA fragmentation is broadly considered a characteristic feature of apoptosis. ${ }^{75}$ Induction of apoptosis can be confirmed by two factors: irregular reduction in size of cells, in which the cells are reduced and shrunken, and DNA fragmentation. ${ }^{43}$ To confirm further the apoptotic features induced by AgNP-treated MDA-MB-231 cells, a DNA-fragmentation assay was conducted. Figure 10 clearly indicates that the DNA-laddering pattern in MDA-MB-231 cells treated with AgNPs is one of the reasons for cell death. Further, to support the data for AgNP-induced apoptosis, apoptotic DNA fragmentation was evaluated by fluorescence microscopy using the TUNEL assay (Figure 11). Treatment of MDAMB-231 cells with AgNPs ( $6 \mu \mathrm{g} / \mathrm{mL})$ revealed a significant appearance of positively labeled cells, representing apoptotic DNA fragmentation. In control cultures, fewer or no apoptotic cells were observed. In contrast, doxorubicin-treated cells showed a significant number of TUNEL-positive cells.
Sriram et $\mathrm{al}^{43}$ demonstrated that Dalton's lymphoma ascite cell lines treated with AgNPs exhibit DNA fragmentation. Genotoxic studies of titanium dioxide NPs revealed dose-dependent DNA damage, chromosomal aberrations, and errors in chromosome segregation, which were due to deposition of metal particles inside the nucleus affecting the DNA and cell division and formation of sister chromatic exchanges. ${ }^{76}$ The toxicity of starch-coated AgNPs was studied using normal human lung fibroblast cells (IMR-90) and human glioblastoma cells (U251), and the results concluded that the toxicity of AgNPs influences cell morphology, cell viability, metabolic activity, and oxidative stress. Further, AgNPs reduced adenosine triphosphate content of the cell, caused damage to mitochondria, and increased production of ROS in a dose-dependent manner. ${ }^{69}$

\section{Conclusion}

We demonstrated the synthesis of AgNPs with a mean size of $5 \mathrm{~nm}$ using pharmaceutically important G. neo-japonicum mycelia extract. These AgNPs showed an absorption peak at $420 \mathrm{~nm}$ in UV-visible spectra, corresponding to the plasmon resonance of AgNPs. TEM and DLS results showed the production of reasonably uniform and monodisperse AgNPs with 
an average particle size of $5 \mathrm{~nm}$. XRD spectra of the NPs confirmed the formation of metallic silver. Further, toxicity studies confirmed the potential cytotoxic effects of biologically synthesized AgNPs in MDA-MB-231 cells. AgNP-treated cells exhibited dose-dependent cell death and membrane leakage. From the cell-proliferation assay, the $\mathrm{IC}_{50}$ was found to be $6.0 \mu \mathrm{g} / \mathrm{mL}$. This report also suggests that AgNPs induce cell death through ROS generation, activation of caspase 3, and DNA fragmentation. This study demonstrates the possibility of using AgNPs to inhibit the growth of cancer cells and their cytotoxicity for potential therapeutic treatments, and offers a new method to combat various diseases, such as cancer, arthritis, and neovascularization.

\section{Acknowledgments}

This research was supported by the University of Malaysia High Impact Research Grant UM MOHE UM.C/625/1/HIR/ MOHE/F00002-21001 from the Ministry of Higher Education Malaysia. Professor Yao Yi-Jian, Director of Fungarium (HMAS), Institute of Microbiology, Chinese Academy of Sciences, Beijing, People's Republic of China is acknowledged for identification of Ganoderma spp. This paper was also supported by the SMART Research Professor Program of Konkuk University. Dr Sangiliyandi Gurunathan was supported by a Konkuk University SMART Full-Time Professorship.

\section{Disclosure}

The authors report no conflicts of interest in this work.

\section{References}

1. Chen X, Schluesener HJ. Nanosilver: a nanoproduct in medical application. Toxicol Lett. 2008;176:1-12.

2. Stensberg MC, Wei Q, McLamore ES, Porterfield DM, Wei A, Sepúlveda MS. Toxicological studies on silver nanoparticles: challenges and opportunities in assessment, monitoring and imaging. Nanomedicine (Lond). 2011;6:879-898.

3. Tian J, Wong KK, Ho CM, et al. Topical delivery of silver nanoparticles promotes wound healing. ChemMedChem. 2007;2:129-136.

4. Malik MA, Brien PO, Revaprasadu N. A simple route to the synthesis of core/shell nanoparticles of chalcogenides. Chem Mater. 2002;14: 2004-2010.

5. Thakkar KN, Mhatre SS, Parikh RY. Biological synthesis of metallic nanoparticles. Nanomedicine. 2010;6:257-262.

6. Parikh RY, Singh S, Prasad BL, Patole MS, Sastry M, Shouche YS. Extracellular synthesis of crystalline silver nanoparticles and molecular evidence of silver resistance from Morganella sp.: towards understanding biochemical synthesis mechanism. Chembiochem. 2008;9:1415-1422.

7. Wani IA, Khatoon S, Ganguly A, Ahmed J, Ahmad T. Structural characterization and antimicrobial properties of silver nanoparticles prepared by inverse microemulsion method. Colloids Surf B Biointerfaces. 2013;101:243-250.

8. Wani A, Ahmad T. Size and shape dependant antifungal activity of gold nanoparticles: a case study of Candida. Colloids Surf B Biointerfaces. 2013;101:162-170.
9. Gurunathan S, Kalishwaralal K, Vaidyanathan R, et al. Biosynthesis, purification and characterization of silver nanoparticles using Escherichia coli. Colloids Surf B Biointerfaces. 2009;74:328-335.

10. Li X, Xu H, Chen Z, Chen G. Biosynthesis of nanoparticles by microorganisms and their applications. J Nanomater. 2011;2011:270974.

11. El-Sonbaty SM. Fungus-mediated synthesis of silver nanoparticles and evaluation of antitumor activity. Cancer Nano. 2013;4:73-79.

12. Ling-Sing Seow S, Naidu M, David P, Wong KH, Sabaratnam V. Potentiation of neuritogenic activity of medicinal mushrooms in rat pheochromocytoma cells. BMC Complement Altern Med. 2013;13: 157.

13. Mukherjee P, Ahmad A, Mandal D, et al. Bioreduction of AuCl(4) (-) ions by the fungus, Verticillium sp. and surface trapping of the gold nanoparticles formed. Angew Chem Int Ed Engl. 2001;40: 3585-3588

14. Ahmad A, Mukherjee P, Senapati S, et al. Extracellular biosynthesis of silver nanoparticles using the fungus Fusarium oxysporum. Colloids Surf B Biointerfaces. 2003;28:313-318.

15. Bhainsa KC, D'Souza SF. Extracellular biosynthesis of silver nanoparticles using the fungus Aspergillus fumigatus. Colloids Surf B Biointerfaces. 2006;47:160-164.

16. Kathiresan K, Manivannan S, Nabeel MA, Dhivya B. Studies on silver nanoparticles synthesized by a marine fungus, Penicillium fellutanum isolated from coastal mangrove sediment. Colloids Surf B Biointerfaces. 2009;71:1133-1137.

17. Philip D. Biosynthesis of $\mathrm{Au}, \mathrm{Ag}$ and $\mathrm{Au}-\mathrm{Ag}$ nanoparticles using edible mushroom extract. Spectrochim Acta A Mol Biomol Spectrosc. 2009;73:374-381

18. Bhat R, Deshpande R, Ganachari SV, Huh DS, Venkataraman A Photo-irradiated biosynthesis of silver nanoparticles using edible mushroom Pleurotus florida and their antibacterial activity studies. Bioinorg Chem Appl. 2011;2011:650979.

19. Ahmad T, Wani IA, Manzoor N, Ahmed J, Asiri AM. Biosynthesis, structural characterization and antimicrobial activity of gold and silver nanoparticles. Colloids Surfa B Biointerfaces. 2013;107: 227-234.

20. Karwa AS, Rai MK. Naturally occurring medicinal mushroom-derived antimicrobials: a case-study using lingzhi or reishi Ganoderma lucidum (W. Curt.:Fr.) P. Karst. (higher Basidiomycetes). Int J Med Mushrooms. 2012;14:481-490.

21. Karwa A, Gaikwad S, Rai MK. Mycosynthesis of silver nanoparticles using lingzhi or reishi medicinal mushroom, Ganoderma lucidum (W. Curt.:Fr.) P. Karst. and their role as antimicrobials and antibiotic activity enhancers. Int J Med Mushrooms. 2011;13:483-491.

22. Maliszewska I, Szewczyk K, Waszak K. Biological synthesis of silver nanoparticles. J Phys Conf Ser. 2009;146:1-6.

23. Jaidev LR, Narasimha G. Fungal mediated biosynthesis of silver nanoparticles, characterization and antimicrobial activity. Colloids Surf B Biointerfaces. 2010;81:430-433.

24. Li T, Luo J, Honda Z, Fukuda T, Kamata N. Sintering condition and optical properties of $\mathrm{Zn}_{3} \mathrm{~V}_{2} \mathrm{O}_{8}$ phosphor. Adv Mater Phys Chem. 2012;2:173-177.

25. Vigneswaran N, Baucum DC, Wu J, et al. Repression of tumor necrosis factor-related apoptosis-inducing ligand (TRAIL) but not its receptors during oral cancer progression. BMC Cancer. 2007;7:108.

26. Chan K, Morris GJ. Chemoprevention of breast cancer for women at high risk. Semin Oncol. 2006;33:642-646.

27. Jenal A, Thomas A, Murray T, Thun M. Cancer statistics, 2002. CA Cancer J Clin. 2002;52:23-47.

28. Johnston SR. Acquired tamoxifen resistance in human breast cancerpotential mechanisms and clinical implications. Anticancer Drugs. 1997;8:911-930.

29. Lupu R, Cardillo M, Cho C, Harris L, Hijazi M. The significance of heregulin in breast cancer tumor progression and drug resistance. Breast Cancer Res Treat. 1996;38:57-66.

30. Brown K. Breast cancer chemoprevention: risk-benefit effects of the antioestrogen tamoxifen. Expert Opin Drug Saf. 2002;1:253-267. 
31. Smith LL, Brown K, Carthew P, Lim CK, Martin EA. Chemoprevention of breast cancer by tamoxifen: risks and opportunities. Crit Rev Toxicol. 2000;30:571-594.

32. Franco-Molina MA, Mendoza-Gamboa E, Sierra-Rivera CA, et al. Antitumor activity of colloidal silver on MCF-7 human breast cancer cells. J Exp Clin Cancer Res. 2010;29:148.

33. Liu H, Liu Y, Wang Z, He P. Facile synthesis of monodisperse, sizetunable SnS nanoparticles potentially for solar cell energy conversion. Nanotechnology. 2010;21:105707.

34. Shin KS, Choi JY, Park CS, Jang HJ, Kim K. Facile synthesis and catalytic application of silver-deposited magnetic nanoparticles. Catal Letters. 2009;133:1-7.

35. Zhou L, He X, He D, Wang K, Qin D. Biosensing technologies for Mycobacterium tuberculosis detection: status and new developments. Clin Dev Immunol. 2011;2011:193963.

36. Ragaseema VM, Unnikrishnan S, Kalliyana Krishnan V, Krishnan LK. The antithrombotic and antimicrobial properties of PEG-protected silver nanoparticle coated surfaces. Biomaterials. 2012;33:3083-3092.

37. Fong J, Wood F. Nanocrystalline silver dressings in wound management: a review. Int J Nanomedicine. 2006;1:441-449.

38. Gurunathana S, Leeb KJ, Kalishwaralala K, Sheikpranbabua S, Vaidyanathana R, Eom SH. Antiangiogenic properties of silver nanoparticles. Biomaterials. 2009;30:6341-6350.

39. AshaRani PV, Low Kah Mun G, Hande MP, Valiyaveettil S. Cytotoxicity and genotoxicity of silver nanoparticles in human cells. ACS Nano. 2009;3:279-290.

40. Kalishwaralal K, Banumathi E, Pandian SBRK, et al. Silver nanoparticles inhibit VEGF induced cell proliferation and migration in bovine retinal endothelial cells. Colloids Surf B Biointerfaces. 2009;73: $51-57$.

41. Park EJ, Yi J, Kim Y, Choi K, Park K. Silver nanoparticles induce cytotoxicity by a Trojan-horse type mechanism. Toxicol In Vitro. 2010;24:872-878.

42. Foldbjerg R, Dang DA, Autrup H. Cytotoxicity and genotoxicity of silver nanoparticles in the human lung cancer cell line, A549. Arch Toxicol. 2011;85:743-750.

43. Sriram MI, Kanth SB, Kalishwaralal K, Gurunathan S. Antitumor activity of silver nanoparticles in Dalton's lymphoma ascites tumor model. Int J Nanomedicine. 2010;5:753-762.

44. Sanpui P, Chattopadhyay A, Ghosh SS. Induction of apoptosis in cancer cells at low silver nanoparticle concentrations using chitosan nanocarrier. ACS Appl Mater Interfaces. 2011;3:218-228.

45. Hsin YH, Chen CF, Huang S, Shih TS, Lai PS, Chueh PJ. The apoptotic effect of nanosilver is mediated by a ROS- and JNK-dependent mechanism involving the mitochondrial pathway in NIH3T3 cells. Toxicol Lett. 2008;179:130-139.

46. Lin ES, Chen YH. Factors affecting mycelial biomass and exopolysaccharide production in submerged cultivation of Antrodia cinnamomea using complex media. Bioresour Technol. 2007;98:2511-2517.

47. Wong KH, Sabaratnam V, Abdullah N, Naidu M, Keynes R. Activity of aqueous extracts of lion's mane mushroom Hericium erinaceus (Bull.: Fr.) Pers. (Aphyllophoromycetideae) on the neural cell line NG108-115. Int J Med Mushrooms. 2007;9:57-65.

48. Gurunathan S, Han JW, Eppakayala V, Jeyaraj M, Kim JH. Cytotoxicity of biologically synthesized silver nanoparticles in MDA-MB-231 human breast cancer cells. Biomed Res Int. 2013;2013:535796.

49. Shim HY, Park JH, Paik HD, Nah SY, Kim DS, Han YS. Acacetininduced apoptosis of human breast cancer MCF-7 cells involves caspase cascade, mitochondria-mediated death signaling and SAPK/JNK1/2-cJun activation. Mol Cells. 2007;24:95-104.

50. Sastry M, Mayyaa KS, Bandyopadhyay K. pH dependent changes in the optical properties of carboxylic acid derivatized silver colloid particles. Colloids Surf A Physicochem Eng Asp. 1997;127:221-228.

51. Sastry M, Patil V, Sainkar SR. Electrostatically controlled diffusion of carboxylic acid derivatized silver colloidal particles in thermally evaporated fatty amine films. $J$ Phys Chem B. 1998;102: 1404-1410.
52. Shankar SS, Ahmad A, Sastry M. Geranium leaf assisted biosynthesis of silver nanoparticles. Biotechnol Prog. 2003;19:1627-1631.

53. Philip D. Biosynthesis of $\mathrm{Au}, \mathrm{Ag}$ and $\mathrm{Au}-\mathrm{Ag}$ nanoparticles using edible mushroom extract. Spectrochim Acta A Mol Biomol Spectrosc. 2009;73:374-381.

54. Mukherjee P, Ahmad A, Mandal D, et al. Fungus-mediated synthesis of silver nanoparticles and their immobilization in the mycelial matrix: a novel biological approach to nanoparticle synthesis. Nano Lett. 2001; 1:515-519.

55. Vigneshwaran N, Kathe KA, Varadarajan PV, Nachane RP, Balasubramanya RH. Silver-protein (core-shell) nanoparticle production using spent mushroom substrate. Langmuir 2007;23: 7113-7117.

56. Kim JS, Kuk E, Yu KN, et al. Antimicrobial effects of silver nanoparticles. Nanomedicine. 2007;3:95-101.

57. Park MV, Neigh AM, Vermeulen J, et al. The effect of particle size on the cytotoxicity, inflammation, developmental toxicity and genotoxicity of silver nanoparticles. Biomaterials. 2011;32:9810-9817.

58. Gopinath P, Gogoi SK, Chattopadhyay A, Sankar Ghosh S. Implications of silver nanoparticle induced cell apoptosis for in vitro gene therapy. Nanotechnology. 2008;19:075104.

59. Piao MJ, Kang KA, Lee IK, et al. Silver nanoparticles induce oxidative cell damage in human liver cells through inhibition of reduced glutathione and induction of mitochondria-involved apoptosis. Toxicol Lett. 2011;201:92-100.

60. Hussain SM, Hess KL, Gearhart JM, Geiss KT, Schlager JJ. In vitro toxicity of nanoparticles in BRL 3 A rat liver cells. Toxicol In Vitro. 2005; 19:975-983.

61. Song XL, Li B, Xu K, et al. Cytotoxicity of water-soluble mPEGSH-coated silver nanoparticles in HL-7702 cells. Cell Biol Toxicol. 2012;28:225-237.

62. Lee YS, Kim DW, Lee YH, et al. Silver nanoparticles induce apoptosis and G2/M arrest via PKCf-dependent signaling in A549 lung cells. Arch Toxicol. 2011;85:1529-1540.

63. Braydich-Stolle LK, Lucas B, Schrand A, et al. Silver nanoparticles disrupt GDNF/Fyn kinase signaling in spermatogonial stem cells. Toxicol Sci. 2010;116:577-589.

64. Carlson C, Hussain SM, Schrand AM, et al. Unique cellular interaction of silver nanoparticles: size dependent generation of reactive oxygen species. J Phys Chem B. 2008;112:13608-13619.

65. Franco-Molina MA, Mendoza-Gamboa E, Sierra-Rivera CA, et al. Antitumor activity of colloidal silver on MCF-7 human breast cancer cells. J Exp Clin Cancer Res. 2010;29:148.

66. Kim S, Ryu DY. Silver nanoparticle-induced oxidative stress, genotoxicity and apoptosis in cultured cells and animal tissues. J Appl Toxicol. 2013;33:78-89.

67. Franco JL, Posser T, Dunkley PR, et al. Methylmercury neurotoxicity is associated with inhibition of the antioxidant enzyme glutathione peroxidase. Free Radic Biol Med. 2009;47:449-457.

68. Asharani PV, Hande MP, Valiyaveettil S. Anti-proliferative activity of silver nanoparticles. BMC Cell Biol. 2009;10:65.

69. Foldbjerg R, Olesen P, Hougaard M, Dang DA, Hoffmann HJ, Autrup H. PVP-coated silver nanoparticles and silver ions induce reactive oxygen species, apoptosis and necrosis in THP-1 monocytes. Toxicol Lett. 2009;190:156-162.

70. Kim S, Choi JE, Chung KH, Park K, Yi J, Ryu DY. Oxidative stress dependent toxicity of silver nanoparticles in human hepatoma cells. Toxicol In Vitro. 2009;23:1076-1084.

71. Martindale JL, Holbrook NJ. Cellular response to oxidative stress: signaling for suicide and survival. $J$ Cell Physiol. 2002;192:1-15.

72. Matsura T, Kai M, Fujii Y, Ito H, Yamada K. Hydrogen peroxide-induced apoptosis in HL-60 cells requires caspase-3 activation. Free Radic Res. 1999;30:73-83.

73. Hu R, Yong KT, Roy I, Ding H, He S, Prasad PN. Metallic nanostructures as localized plasmon resonance enhanced scattering probes for multiplex dark field targeted imaging of cancer cells. J Phys Chem C Nanomater Interfaces. 2009;113:2676-2684. 
74. Allen RT, Hunter WJ, Agrawal DK. Morphological and biochemical characterisation and analysis of apoptosis. J Pharmacol Toxicol Methods. 1997;37:215-228.
75. Wang J, Zhou G, Chen C, Yu H, Wang T. Acute toxicity and biodistribution of different sized titanium dioxide particles in mice after oral administration. Toxicol Lett. 2007;168:176-185.

\section{Publish your work in this journal}

The International Journal of Nanomedicine is an international, peerreviewed journal focusing on the application of nanotechnology in diagnostics, therapeutics, and drug delivery systems throughout the biomedical field. This journal is indexed on PubMed Central,

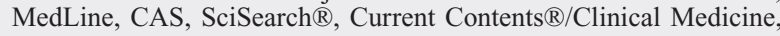

Journal Citation Reports/Science Edition, EMBase, Scopus and the Elsevier Bibliographic databases. The manuscript management system is completely online and includes a very quick and fair peer-review system, which is all easy to use. Visit http://www.dovepress.com/ testimonials.php to read real quotes from published authors.

Submit your manuscript here: http://www.dovepress.com/international-journal-of-nanomedicine-journal 